\title{
Effect of Sewage Sludge and Cadmium on Growth and Quality Features of Marigold (Tagetes erecta L.) Grown in Three Soils
}

\author{
Archana Gupta, B.R. Maurya and A.M. Latare* \\ Department of Soil Science and Agricultural Chemistry, Institute of Agricultural Sciences, \\ Banaras Hindu University, Varanasi, 221005, India \\ *Corresponding author
}

\author{
A B S T R A C T
}

The present investigation was conducted to study the effect of sewage sludge and cadmium on growth and quality features of marigold (Tagetes erecta L.). The experiment was conducted in Factorial Complete Randomized Design. The treatments consisted of four

Keywords

Marigold, Sewage sludge, Cadmium, Growth and quality.

Article Info

Accepted:

23 August 2017

Available Online:

10 September 2017 doses of sewage sludge $\left(0,5,10\right.$ and $\left.15 \mathrm{~g} \mathrm{~kg}^{-1}\right)$ in combination with three doses of cadmium $\left(0,20\right.$ and $\left.40 \mathrm{mg} \mathrm{kg}^{-1}\right)$ taking three replications. The treatments were studied in three types of soils Alluvial, Red and Black soil. In the present study, plant height, the number of branch per plant, shoot fresh weight, shoot dry matter, flower height, compactness, flower diameter and shelf life of flower were measured. Results revealed that the application of sludge and cadmium significantly influenced the plant growth properties. The interaction effect of sludge and cadmium was not significant on studied characters except for flower height, compactness and shelf life. The highest plant height, number of branches per plant, shoot fresh and dry weight, flower diameter was obtained with $15 \mathrm{~g} \mathrm{~kg}^{-1}$ sludge amended soil. The treatment applied with higher dose of Cd (40 mg $\mathrm{kg}^{-1}$ ) without sewage sludge showed minimum shoot fresh and dry weight. It was found that application of sewage sludge can reduce the toxicity effect of cadmium. In general, black soils showed more response to sewage sludge and $\mathrm{Cd}$ which was clearly evident from higher values in respective treatments compared to red and alluvial soils.

\section{Introduction}

Industrial and agricultural activities have led to a considerable increase in heavy metals in the different environmental compartments especially in soil over the course of recent decades. There are some reports which indicate that heavy metals pollution in soil arises as a result of various anthropogenic activities such as continuous use of sewage water, sewage sludge and fertilizers.

Among the various types of heavy metals, cadmium is one of the most toxic trace metal having toxicity 2-20 times higher than many other heavy metals and it is easily transferable in food chain through soil and environment. Cadmium is found mainly in association with zinc sulfide based ores in a ratio of about 1:100 and to a lesser degree as an impurity in lead and copper ores. The average cadmium content of the lithosphere is estimated at 0.2 $\mathrm{mg} \mathrm{kg}^{-1}$ and the range for soils is found as 0.01 to $0.7 \mathrm{mg} \mathrm{kg}^{-1}$ (Das 2000). Fossil fuels contain 0.5 to $1.5 \mathrm{ppm} \mathrm{Cd}$, but phosphate fertilizers contain from 10 to $200 \mathrm{ppm} \mathrm{Cd}$ 
(Cook and Morrow 1995). In natural soils, the amount of $\mathrm{Cd}$ content varies with the types of parent material. $\mathrm{Cd}$ in soils is derived from both natural and anthropogenic sources. The major natural sources for mobilizations of $\mathrm{Cd}$ from the earth's crust are volcanoes and weathering of rocks. Cadmium is a naturallyoccurring constituent in a wide range of materials which are utilized for industrial and consumer purposes. It is sometimes found in high concentrations in phosphate fertilizers since some marine phosphates and phosphorites have been reported to contain cadmium levels as high as 500 ppm (WHO 1992, Cook and Morrow 1995).

Cadmium has a very limited downward movement in soil and is thus usually retained in the top 0-15 cm layer of soil (Chang et al., 1984). The impact of $\mathrm{Cd}$ contamination on agricultural soils depends on soil physical, chemical and biological properties which influence plant uptake and availability of cadmium. Soil properties affect metal bioavailability to ecological receptors. The lower availability of cadmium in Inceptisol may be due to the fixation in clay, hydrous oxides of iron and manganese while clay fixation and precipitation as insoluble sulphides of cadmium may be ascribed in the Ultisol. The lower extractability of cadmium in Vertisol might be due to the formation of its relatively insoluble carbonate.

Excess $\mathrm{Cd}$ causes inhibition and abnormalities of general growth in many plant species. Visible symptoms of cadmium toxicity in plant leave include rolling, browning, chlorosis, reddish veins and petioles causing severe reduction in growth (Tran and Popova 2012). In case of human nutrition, $\mathrm{Cd}$ is a cumulative poison. It is mainly accumulated in the kidneys and to some extent also in the liver and spleen. Excess $\mathrm{Cd}$ causes damage to the kidney tubules, rhinitis, emphysema as well as other chronic disorders.
Production of huge amount of sewage sludge due to industrialization and urbanization, has created serious environmental problems for their disposal. Use of sewage sludge on agricultural land has become a common practice in India and is a very effective disposal technique. Sewage sludge, being organic waste, is a good source of plant nutrients such as $\mathrm{N}, \mathrm{P}, \mathrm{K}, \mathrm{S}, \mathrm{Ca}, \mathrm{Mg}, \mathrm{Fe}, \mathrm{Cu}$, $\mathrm{Mn}$ and $\mathrm{Zn}$ as well as other organic constituents (Martinez et al., 2003). Sewage sludge application in agricultural soils is of most important in maintaining the tilth, fertility and productivity of the soils. It improves soil physical, chemical and biological properties such as porosity, aggregate stability, bulk density, soil fertility, water movement and retention. The application of sewage sludge to agricultural land enables us to reduce the use of artificial fertilizer and makes good use of resource.

Besides its nutritional value, it may also contain toxic heavy metals such as $\mathrm{Cd}, \mathrm{Cr}, \mathrm{Ni}$, $\mathrm{Pb}, \mathrm{As}, \mathrm{Hg}$ etc. Some of the heavy metals at low doses are essential micronutrients for plants but in higher doses, may cause metabolic disorder and growth inhabitation for most of the plant species. The addition of sewage sludge to the soil diminishes the inhibitory effect of $\mathrm{Cd}$ on biological parameters. The addition of this kind of organic material can help in the remediation of $\mathrm{Cd}$ polluted soils provided the heavy metal content of the organic material is very low.

Marigold is widely used in India for religious purpose, decorations and offerings. It performs well in hot, dry climate. Marigold is short duration free flowering, hairy, hard and evergreen crop. The pigments in marigold are sometime extracted and used as a food colouring for human and livestock. Marigold is used as a medicinal, flavouring, dye and ornamental plant. The use of marigold is associated with marriage, social function and 
festivals. The flower is endued with spectrum of attraction colour, shape and size along with its keeping quality. Besides its pristine uses as cut flower for interior decorator in hanging basket, rock garden for landscaping purpose and for the beautification of halls.

African marigold (Tagetes erecta L.) is one of the earliest annual flowers to cultivate and has been widely adapted to different soils and climate condition. Marigold can uptake higher amount of $\mathrm{Cd}$ and accumulate in their body without showing toxicity symptoms. Sewage sludge being a rich source of nutrients and organic matter improves soil properties and can reduce the toxicity of $\mathrm{Cd}$ by forming clay humus complexes in soil.

Thus, keeping in view, the present investigation was done in order to evaluate the effect of sewage sludge and cadmium on growth and quality characteristics of marigold (Tagetes erecta L.).

\section{Materials and Methods}

\section{Study area}

The experiment was conducted as a pot culture study in the glass house of the Department of Soil Science and Agricultural Chemistry, Institute of Agricultural Sciences, Banaras Hindu University, Varanasi, India, during July 2011 to April 2012. The Varanasi is located between the parallels of $25.14^{\circ}$ and $25.23^{\circ} \mathrm{N}$ latitude and $82.56^{\circ}$ and $83.03^{\circ} \mathrm{E}$ longitude and falls in a semi-arid to sub humid climate with moisture deficit index between 20 - 40 .

\section{Collection of soil and sewage sludge}

To conduct the pot experiment, the alluvial soil fine loamy, mixed hyperthermic, typic Ustochrepts was collected from Agricultural Research Farm, Banaras Hindu University,
Varanasi. Red fine loamy, mixed hyperthermic, typic Rhodustalfs was collected from Rajiv Gandhi South Campus, Barkachha, Mirzapur. Black soil fine loamy, mixed hyperthermic, entic Chromusterts was collected from village Shahanshahpur, Varanasi. The soil was ground to pass through $2 \mathrm{~mm}$ sieve and four $\mathrm{kg}$ of soil was filled in each pot. Sewage sludge was collected from Sewage Treatment Plant (STP) Bhagwanpur, Varanasi in the month of October 2011. The sewage sludge was dry at the time of collection it was then grounded to get homogenous mass.

\section{Experimental design and raising of plants}

The experiment was conducted in Factorial Complete Randomized Design. Marigold (Tagetes erecta var. Inka) was chosen as the test crop. One month old seedlings were used for transplanting purpose. The treatments consisted of four doses of sewage sludge $(0$, 5,10 and $\left.15 \mathrm{~g} \mathrm{~kg}^{-1}\right)$ in combination with three doses of cadmium $\left(0,20\right.$ and $\left.40 \mathrm{mg} \mathrm{kg}^{-1}\right)$ applied through $3 \mathrm{CdSO}_{4} \cdot 8 \mathrm{H}_{2} \mathrm{O}$. Four $\mathrm{kg}$ soil was filled in each pot and required quantities of fertilizers were applied in liquid form using urea, S.S.P and muriate of potash as source of $\mathrm{N}, \mathrm{P}$ and $\mathrm{K}$, respectively. The recommended dose of N, P and $\mathrm{K}$ was taken as 200, 80 and $80 \mathrm{~kg} \mathrm{ha}^{-1}$ respectively. Half of $\mathrm{N}$ and full dose of $\mathrm{P}$ and $\mathrm{K}$ was applied at the time of transplanting of marigold and remaining $\mathrm{N}$ fertilizer was applied in the equal splits at 30 and 60 days after transplanting. Crop was harvested at 80 days after transplanting.

\section{Observations recorded}

The plant height, number of primary branch per plant, shoot fresh weight, shoot dry matter, chlorophyll content, number of flower, flower fresh weight, flower dry weight, compactness, flower height, flower diameter and shelf life were measured. 
Plant height was measured from the surface of soil to the tip of plant with the help of a meter scale. Plants from each pot were cut with the help of scissors from $2 \mathrm{~cm}$ above surface of soil and the fresh weight was recorded by using electronic balance. Plant samples were kept in paper bags and dried in hot air oven at $60 \pm 2{ }^{\circ} \mathrm{C}$ till constant weight and their dry weight was recorded by an electronic balance.

The chlorophyll content was measured by using a SPAD (Soil Plant Analysis Device) at harvest by selecting six leaves randomly at the centre of the branch and the average was worked out. The total number of primary branches was counted at the time of harvest and averaged. Number of flowers pot ${ }^{-1}$ was counted at the time of harvest. Fully opened flowers were regularly harvested and just after harvesting their weight were taken by electronic balanced and expressed in gram. Diameter of flower was measured at the point maximum breadth and the average diameter was recorded with the help of Vernier caliper when flowers were fully opened and expressed in $\mathrm{cm}$. Compactness was measured by noting the maximum breadth, after that the flowers were pressed and diameter was measured with Vernier caliper for minimum breadth. Compactness percentage was calculated by the following formula:

Compactness $=$ maximum $\quad$ breadth $/$ minimum breadth $\mathrm{x} 100$

Height of three flowers was measured with the help of Vernier caliper and their mean was calculated and expressed in $\mathrm{cm}$. Shelf life of the flowers was assessed by recording the number of days up to which 50 per cent or more flowers maintained freshness without exhibiting brown pigmentation.

Four randomly selected flowers in each treatment were kept in room temperature for taking shelf life.

\section{Statistical analysis}

The statistical analysis was done using Factorial Complete Randomized Design with twelve treatments and three replications. The analysis was carried using two-way analysis of variance (ANOVA) by the method described by Gomez and Gomez, (1984) to test the significance of difference between the treatments. The test of significance was carried out at $5 \%$ level of significance by referring to ' $\mathrm{F}$ ' table values.

\section{Results and Discussion}

\section{Sewage sludge characteristics}

The digested sewage sludge had $\mathrm{pH}$ (6.43), EC $\left(2.88 \mathrm{dS} \mathrm{m}^{-1}\right)$, organic $\mathrm{C}(11.32 \%)$, available $\mathrm{N}, \mathrm{P}$ and $\mathrm{K}$ content as 176.4, 52.2 and $173.4 \mathrm{mg} \mathrm{kg}^{-1}$, respectively. DTPA extractable contents of $\mathrm{Fe}, \mathrm{Mn}, \mathrm{Cu}$ and $\mathrm{Zn}$ of sludge were 78.9, 36.5, 23.2 and $17.5 \mathrm{mg}$ $\mathrm{kg}^{-1}$, respectively. The permissible levels for potential toxic elements such as $\mathrm{Zn}, \mathrm{Cu}, \mathrm{Cd}$, $\mathrm{Pb}, \mathrm{Ni}$ and $\mathrm{Cr}$ in sludge to be used in agricultural soils are 2500, 1000, 20, 750, 300 and $750 \mathrm{mg} \mathrm{kg}^{-1}$, respectively according to Council of the European Communities (1986). As regards to $\mathrm{Cd}, \mathrm{Cr}, \mathrm{Ni}$ and $\mathrm{Pb}$ the DTPA extractable amounts were 3.12, 7.90, 12.9 and $39.6 \mathrm{mg} \mathrm{kg}^{-1}$, respectively. Hence the sewage sludge used in the present study had heavy metals content below the maximum permissible limits.

\section{Effect of sludge and cadmium on plant height, fresh and dry weight}

The plant height was significantly $(\mathrm{p} \leq 0.01)$ affected by sewage sludge and cadmium (Table 1). In alluvial soil it varied from 18.4 to $24.1 \mathrm{~cm}$, whereas, in red and black soil it ranged from 18.8 to $23.7 \mathrm{~cm}$ and 21.1 to 24.5 $\mathrm{cm}$, respectively. It was found that the plant height gradually decreased with increase in 
soil Cd content, whereas, significant increase was recorded with sewage sludge application. The maximum plant height in all the three soil types was found in the treatment amended with $15 \mathrm{~g} \mathrm{~kg}^{-1}$ sludge $\left(\mathrm{Cd}_{0} \mathrm{~S}_{15}\right)$ which showed 16,14 and $7 \%$ increase over control $\left(\mathrm{Cd}_{0} \mathrm{~S}_{0}\right)$ in alluvial, red and black soil, respectively. The interaction effect of sewage sludge with cadmium was also significant. Sole application of $40 \mathrm{mg} \mathrm{kg} \mathrm{mg}^{-1} \mathrm{Cd}\left(\mathrm{Cd}_{40} \mathrm{~S}_{0}\right)$ significantly decreased the plant height by 14 , 4 and $6 \%$ over control $\left(\mathrm{Cd}_{0} \mathrm{~S}_{0}\right)$ in alluvial, red and black soil, respectively. The significant increase in plant height was observed for higher doses of sewage sludge i.e. 10 and $15 \mathrm{~g}$ $\mathrm{kg}^{-1}$ sludge in all the three soil types. The height was in order black $>$ alluvial $>$ red.

Sewage sludge is rich in organic matter; therefore, it supplies most of the major and micronutrients for plant growth. The $\mathrm{N}$ is released after subsequent decomposition which improves the growth of plants. Also it functions to bind the heavy metals in soil by forming chelates. This might be a probable reason for reducing the toxicity of $\mathrm{Cd}$ in sludge amended soil and improving the growth of plant. The lower plant height in $\mathrm{Cd}$ amended treatments might be due to the toxicity of $\mathrm{Cd}$. Toxicity of $\mathrm{Cd}$ may result from the binding of metals to sulphydryl groups in proteins, leading to an inhibition of enzymatic activity or disruption of structure (Van Assche and Clijsters 1990). This was also supported by Zhou and Qiu (2005) that high concentrations of $\mathrm{Cd}$ cause toxicity in plants at it causes growth inhibition of root and shoot, leaf roll, and chlorosis and eventually plant death due to the reduction of enzyme activity, photosynthesis, respiration and transpiration and nutrient uptake.

The fresh weight of plant at harvest in alluvial, red and black soil ranged between 48.6 to $64.8,30$ to 47.8 and 50.6 to $72.2 \mathrm{~g}$, respectively. Treatment $\mathrm{Cd}_{0} \mathrm{~S}_{15}$ showed 9, 19 and $13 \%$ increase over control $\left(\mathrm{S}_{0} \mathrm{Cd}_{0}\right)$, in alluvial, red and black soil, respectively. The treatments amended with 20 and $40 \mathrm{mg} \mathrm{kg}^{-1}$ $\mathrm{Cd}$ without sludge (treatments $\mathrm{Cd}_{20} \mathrm{~S}_{0}$ and $\mathrm{Cd}_{40} \mathrm{~S}_{0}$ ) showed 13 and $22 \%$ reduction in fresh weight in alluvial soil, whereas, the corresponding reduction in red soil was 10 and $34 \%$ and in black soil it was 12 and $26 \%$ over control, respectively. The dry weight of plant at harvest in alluvial and red soil ranged between 13.1 to $17.2 \mathrm{~g}$ and 12.4 to $16.1 \mathrm{~g}$, whereas, in black soil it varied from 13.9 to $19.5 \mathrm{~g}$. Sole application of 10 and $15 \mathrm{~g} \mathrm{~kg}^{-1}$ SS (treatments $\mathrm{Cd}_{0} \mathrm{~S}_{10}$ and $\mathrm{Cd}_{0} \mathrm{~S}_{15}$ ) increased the dry weight of plant at harvest by 15 and $21 \%$ in alluvial soil, 14 and $20 \%$ in red soil and 11 and $19 \%$ in black soil, respectively over control $\left(\mathrm{Cd}_{0} \mathrm{~S}_{0}\right)$. It was found that the fresh and dry weight of plant gradually decreased with increase content of $\mathrm{Cd}$ in soil, whereas, application of sewage sludge increased the fresh weight. The maximum fresh and dry weight of plant in all three soil types was found in the treatment amended with $15 \mathrm{~g} \mathrm{~kg}^{-1}$ sewage sludge $\left(\mathrm{Cd}_{0} \mathrm{~S}_{15}\right)$.

Reduction in fresh and dry weight of plant was recorded in $\mathrm{Cd}$ treated soil. Red soils showed lowest fresh and dry weight in all the treatments compared to alluvial and black soil. This might be due to the higher availability of $\mathrm{Cd}$ in red soil due to low $\mathrm{pH}$. The results corroborate the findings of Gupta et al., (2009), their study revealed that the toxic effect of $\mathrm{Cd}$ pollution to plants was more in soils of low $\mathrm{pH}$ as compared to soils of higher pH. Kibria et al., (2006) reported that $9 \mathrm{mg} \mathrm{kg}^{-1} \mathrm{Cd}$ decreased $17-35 \%$ shoot weight of rice. Muramoto et al., (1990) also reported that shoot weight $21 \%$ reduced by $100 \mathrm{mg} \mathrm{kg}^{-1} \mathrm{Cd}$. John et al., (1972) reported effect of $\mathrm{Cd}$ on radish growth with 30 different surface soil. Shoot weight was reduced an average $47 \%$ by addition $100 \mathrm{mg}$ $\mathrm{kg}^{-1} \mathrm{Cd}$. Lettuce growth was reduced by $23 \%$

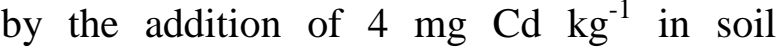


investigated by Sadana and Singh (1987). Wu et al., (2007) also observed that increasing $\mathrm{Cd}$ levels in the medium cause a significant decreased in height and fresh weight of different barley genotypes.

Adhikari et al., (2005) found that application of $\mathrm{Cd}$ decreased the dry matter of spinach by $38 \%$ reduction in dry weight of plant compared with control. Liu et al., (2011) reported that shoot of $T$. patula can reach to $1800 \mathrm{mg}$ plant ${ }^{-1}$ DW. Thus, T. patula shows promised potential as a $\mathrm{Cd}$ accumulator for phytoremediation in $\mathrm{Cd}$ contaminated soil. The reduction in dry weight of spinach with increasing $\mathrm{Cd}$ application to soil may be due to the combined effect of $\mathrm{Cd}$ toxicity and ion imbalance (Root et al., 1975). Similar result reported by Dalir et al., (2013) found that application of $80 \mathrm{mg} \mathrm{kg}^{-1} \mathrm{Cd}$ decreased dry weight from 3.43 (control) to $0.197 \mathrm{~g} \mathrm{pot}^{-1}$, i.e. a $97 \%$ decrease in plant growth.

Sewage sludge is a good source of major and micronutrients, its subsequent decomposition might have provided the nutrients to the plant resulting into the increase in dry matter accumulation. With the increase in levels of $\mathrm{Cd}$ the dry matter accumulation was found to be decreased. The interaction effect of $\mathrm{Cd}$ with sludge was also significant in all three soil types. The reduction in plant growth and dry matter yield with increasing soil metal load was reported by many workers (Chaudhary et al., 2004; Sharma and Agrawal 2005; Chatterjee et al., 2006; Wani et al., 2007 and Hussain et al., 2008).

Effect of sludge and cadmium on chlorophyll content and number of branches

The maximum leaf chlorophyll content at harvest (table 2) in alluvial (60.4 SPAD), red (56.5 SPAD) and black (63.0 SPAD) was found in the treatment amended with $15 \mathrm{~g} \mathrm{~kg}^{-1}$ SS $\left(\mathrm{S}_{15} \mathrm{Cd}_{0}\right)$, whereas, the lowest was recorded in treatment amended with $40 \mathrm{mg}$ $\mathrm{kg}^{-1} \mathrm{Cd}\left(\mathrm{Cd}_{40} \mathrm{~S}_{0}\right)$. Sole application of $40 \mathrm{mg}$ $\mathrm{kg}^{-1} \mathrm{Cd}\left(\mathrm{Cd}_{40} \mathrm{~S}_{0}\right)$ significantly decreased the leaf chlorophyll content by 8,8 and $11 \%$ over control $\left(\mathrm{Cd}_{0} \mathrm{~S}_{0}\right)$ in alluvial, red and black soil, respectively. The significant increase in plant height was observed for higher doses of sewage sludge i.e. 10 and $15 \mathrm{~g} \mathrm{~kg}^{-1} \mathrm{SS}$ in all the three soil types. Nitrogen is an essential component of chlorophyll structure, sewage sludge being organic fertilizer, contains $\mathrm{N}$ in available as well as combined form. This bound form of $\mathrm{N}$ releases after subsequent decomposition and is available to plant. This might be a probable reason for the increase in chlorophyll content in marigold. The chlorophyll content decreased with the increase in $\mathrm{Cd}$ content, this might be due to the higher uptake of $\mathrm{Cd}$ in plant tissue.

Stobart et al., (1985) suggested that decline in the chlorophyll level might be due to the Cdinduced inhibition at protochlorophyllide stage which in sequence obstructs the activity of enzyme protochlorophyllide reductase. The reduction in chlorophyll due to excess level of Cd was reported by Wani et al., (2007). Padmaja et al., (1990) proposed that Cd induced inhibition of chlorophyll biosynthesis could be a result of diminishing level of $\delta$ aminolevulinic acid dehydrogenase and dissociation of pigment or its precursors. Rai et al., (2005) reported that the degree of depression in the pigments of Phyllanthus at Cd $(100 \mu \mathrm{M})$ were about $30 \%$ for chlorophyll $\mathrm{a}, 48 \%$ for chlorophyll $\mathrm{b}$ and $40 \%$ for carotenoid which implied that chlorophyll $b$ was severely affected than chlorophyll a; hence showed an increase in chlorophyll $\mathrm{a} / \mathrm{b}$ ratio. Liu et al., (2011) reported that after 14 days, chlorophyll content in T. patula leaves decreased by 45 and $74 \%$ with 25 and $50 \mu$ $\mathrm{M} \mathrm{CdCl}_{2}$ as compared to control.

The number of branches increased significantly with application of sewage sludge, while significantly decreased with 
increasing levels of cadmium. It varied from 9.67 to $15.2,11.0$ to 14.3 and 9.8 to 15.2 in alluvial, red and black soil, respectively. Application of $15 \mathrm{~g} \mathrm{~kg}^{-1}$ sewage sludge significantly increased the number of branches by 27 and $23 \%$ over control in alluvial and black soil, respectively, while the effect was non-significant in red soil. The number of branches due to $\mathrm{Cd} 20$ and $40 \mathrm{mg}$ $\mathrm{kg}^{-1}$ with $15 \mathrm{~g} \mathrm{~kg}^{-1}$ sewage sludge (treatment $\mathrm{Cd}_{20} \mathrm{~S}_{15}$ and $\mathrm{Cd}_{40} \mathrm{~S}_{15}$ ) reduced by 11 and $23 \%$, 10 and $15 \%$ and 14 and $18 \%$ in alluvial, red and black soil, respectively compared with sole application of $15 \mathrm{~g} \mathrm{~kg}^{-1}$ sewage sludge. The number of branches significantly decreased with treatment $\mathrm{Cd}_{20} \mathrm{~S}_{0}$ and $\mathrm{Cd}_{40} \mathrm{~S}_{0}$ by 11 and $23 \%$ in alluvial soil, whereas, 10 and $17 \%$ in red soil and 17 and $25 \%$ in black soil, respectively over control. The interaction effect of $\mathrm{Cd}$ and sewage sludge was nonsignificant in all three soil types.

This might be a probable reason for increased number of branches, because it supplies higher amount of $\mathrm{N}$ after subsequent decomposition which improves the growth of plants (Rathore et al., 1985). Similar result was also reported by Ahamad et al., (2010). The $\mathrm{Cd}$ in plant cell reacts with pectin in plant cell. The cross linking of pectin in the middle lamella is responsible for inhibition of cell expansion resulting deceased plant growth (Prasad 1995). In the present study higher levels of $\mathrm{Cd}$ were applied this might have caused cell wall dysfunction and reduced number of branches.

\section{Effect of sewage sludge and cadmium on flower number, fresh and dry weight}

The fresh and dry weight of flowers per plant significantly varied with sewage sludge and cadmium, but, the interaction effect was nonsignificant (table 3). The fresh weight of flowers per plant in alluvial soil ranged between 23.3 to $57.8 \mathrm{~g}$, whereas, in red and black soil it ranged between 14.5 to $53.4 \mathrm{~g}$ and 29.9 to $79.2 \mathrm{~g}$. The maximum fresh weight was showed with treatment $\mathrm{Cd}_{0} \mathrm{~S}_{15}$ by 89, 119 and $91 \%$ increase over control $\left(\mathrm{S}_{0} \mathrm{Cd}_{0}\right)$, in alluvial, red and black soil, respectively. Sole application of 20 and 40 mg kg ${ }^{-1} \mathrm{Cd}$ (treatments $\mathrm{Cd}_{20} \mathrm{~S}_{0}$ and $\mathrm{Cd}_{40} \mathrm{~S}_{0}$ ) significantly decreased the fresh weight of flower by 11 and $31 \%$ over control $\left(\mathrm{Cd}_{0} \mathrm{~S}_{0}\right)$ in alluvial soil, 22 and $68 \%$ in red soil and 21 and $39 \%$ in black soil. The treatment $\mathrm{Cd}_{0} \mathrm{~S}_{15}$ showed 65, 68 and 64\% higher fresh weight of flowers per plant over $\mathrm{Cd}_{40} \mathrm{~S}_{15}$ in alluvial, red and black soil, respectively. Maximum dry weight was recorded with treatment $\mathrm{Cd}_{0} \mathrm{~S}_{15}$ by 67,70 and $73 \%$ increase over control $\left(\mathrm{S}_{0} \mathrm{Cd}_{0}\right)$, in alluvial, red and black soil, respectively. Single application of 20 and 40 mg kg ${ }^{-1} \mathrm{Cd}$ (treatments $\mathrm{Cd}_{20} \mathrm{~S}_{0}$ and $\mathrm{Cd}_{40} \mathrm{~S}_{0}$ ) significantly decreased the dry weight of flower by 14 and $33 \%$ over control $\left(\mathrm{Cd}_{0} \mathrm{~S}_{0}\right)$ in alluvial soil, 26 and $69 \%$ in red soil and 24 and $34 \%$ in black soil. The treatment $\mathrm{Cd}_{0} \mathrm{~S}_{15}$ showed 48, 30 and 43\% higher dry weight of flowers per plant over $\mathrm{Cd}_{40} \mathrm{~S}_{15}$ in alluvial, red and black soil, respectively.

The fresh and dry weight of flowers per plant decreased with increase in soil $\mathrm{Cd}$ content, whereas, it increased with graded levels of sewage sludge. The maximum fresh and dry weight of flowers plant ${ }^{-1}$ in all the three soil types was found in the treatment amended with $15 \mathrm{~g} \mathrm{~kg}^{-1} \mathrm{SS}\left(\mathrm{Cd}_{0} \mathrm{~S}_{15}\right)$. Amongst the three soil types the maximum fresh and dry weight of flower in respective treatments was reported in black soil.

\section{Effect of sewage sludge and cadmium on flower quality}

The compactness of flower and flower height in alluvial, red and black soils increased with increase in levels of sewage sludge and decreased with cadmium levels but the effect was non-significant except $\mathrm{Cd}$ in red soil 
(table 4). The interaction effect of $\mathrm{Cd}$ and sewage sludge was also non-significant in all three soil types. There was no clear visible effect observed in compactness of marigold flower due to sewage sludge and cadmium. The flower compactness at harvest in alluvial and red soil ranged between 70.67 to 76.33 $\mathrm{cm}$ and 71.00 to $75.33 \mathrm{~cm}$, whereas, in black soil it varied from 73.67 to $77.00 \mathrm{~cm}$. The maximum flower compactness in alluvial $(76.33 \mathrm{~cm})$ and red soil $(75.33 \mathrm{~cm})$ was recorded with $\mathrm{Cd}_{40} \mathrm{~S}_{5}$, whereas, in black soil $(77.0 \mathrm{~cm})$ it was observed with $\mathrm{Cd}_{0} \mathrm{~S}_{10}$. The lowest compactness of flower in alluvial, red and black soil was observed in treatment $\mathrm{Cd}_{20} \mathrm{~S}_{0}, \mathrm{Cd}_{20} \mathrm{~S}_{10}$ and $\mathrm{Cd}_{40} \mathrm{~S}_{0}$, respectively.

The flower height at harvest in alluvial and red soil ranged between 3.37 to $3.86 \mathrm{~cm}$ and 3.29 to $3.88 \mathrm{~cm}$, whereas, in black soil it varied from 3.49 to $3.86 \mathrm{~cm}$. The maximum flower height in alluvial $(3.86 \mathrm{~cm})$, red $(3.88$ $\mathrm{cm})$ and black soil $(3.86 \mathrm{~cm})$ was recorded in treatment $\mathrm{Cd}_{0} \mathrm{~S}_{15}$, whereas, minimum was recorded with $\mathrm{Cd}_{20} \mathrm{~S}_{0}$ in alluvial soil and with $\mathrm{Cd}_{40} \mathrm{~S}_{0}$ in red and black soil.

The flower diameter of marigold varied significantly with cadmium, but the effect was non-significant with sewage sludge, the interaction effect was also non-significant. The flower diameter in alluvial soil ranged between 6.02 to $6.83 \mathrm{~cm}$, whereas, in red and black soil it ranged between 4.71 to $6.36 \mathrm{~cm}$ and 6.60 to $7.01 \mathrm{~cm}$. In general the flower diameter decreased with increase in soil $\mathrm{Cd}$ content, whereas, it increased with graded levels of sewage sludge.

The maximum flower diameter in all the three soil types was found in the treatment amended with $15 \mathrm{~g} \mathrm{~kg}^{-1} \mathrm{SS}\left(\mathrm{Cd}_{0} \mathrm{~S}_{15}\right)$, whereas the lowest was in treatment $\mathrm{Cd}_{40} \mathrm{~S}_{0}$. Amongst the three soil types the maximum flower diameter of flower in respective treatments was reported in black soil.
The shelf life of flowers in alluvial, red and black soil ranged between 4 to 5 days. It was found that the shelf life of flowers was nonsignificantly affected by sewage sludge and cadmium application. Sewage sludge being organic rich material supplies all essential nutrients for plant growth, resulting into the improved quality of flowers. The higher shelf life in some treatments might be due to the improved quality of flowers. It is evidence that storage temperature is the most important abiotic factor that affects the shelf-life (Connick et al., 1997; Elzein et al., 2004) by maintaining them in a state of low metabolic activity (Elzein et al., 2004).

Sewage sludge is widely applied in crop production and provide proper supplements for chemical fertilizers. Application of sewage sludge significantly improved plant growth and quality characteristics of marigold. Maximum of plant growth features such as plant height, fresh and dry weight, chlorophyll content of leaf and the number of branches was obtained with $15 \mathrm{~g} \mathrm{~kg}^{-1}$ sewage sludge amended soils, whereas, quality characteristics of flower i.e., flower diameter and flower height were non significantly increased with graded application of sewage sludge in all three soils. Amongst the three soil types the maximum plant height, fresh and dry weight of plant was reported in black soil. There was no clear evidence of effect of sewage sludge and cadmium on flower compactness and shelf life. Therefore, it may be concluded that, sewage sludge can be used in cadmium contaminated soil for growing marigold crop.

\section{References}

Adhikari, T., Biswas, A.K. and Saha, J.K. 2005. Cadmium phytotoxicity in spinach with or without spent wash in a Vertisol. Communications in Soil Science and Plant Analysis. 36(11- 
12):1499-1511.

Ahmad, I., Asif. M., Amjad, A. and Ahmad, S. 2011. Fertilization enhances growth, yield and xanthophyll contents of marigold. Turkish Journal of Agriculture and Forestry. 35: 641-648.

CEC (Council of the European Communities), 1986. Council Directive of 12 June 1986 on the protection of environment and in particular of the soil, when sewage sludge is used in agriculture (86/278/EEC) Off. Journal of European Communities. 181, 6-12.

Chang, A.C., Warneko, J.E., Page, A.C., Lund, L.S., 1984. Accumulation of heavy metals in sludge-treated soils. Journal of Environmental Quality. 13(1): 87-91.

Chatterjee, S., Chattopadhyay, B., Dutta, S., Mukhopadhyay, S.K., 2006. Heavy metals phytoremediation at contaminated East Calcutta Wetlands. Journal of Natural History. 2, 17-28.

Chaudhary, P., Dubeja, S.S., Kapoor, K.K., 2004. Effectivity a host Rhizobium leguminosarum symbiosis in soils receiving sewage water containing heavy metals. Microbiological Research. 159, 121-127.

Connick, W.J., Jackson, M.A., Williams, K.S., Boyette, C.D., 1997. Stability of microsclerotial inoculum of Colletotrichum truncatum encapsulated in wheat flour-kaolin granules. World Journal of Microbiology and Biotechnology. 13, 549-554.

Cook, M.E., Morrow, H., 1995. Anthropogenic Sources of Cadmium in Canada. In National Workshop of Cadmium Transport into Plants (Centres Canadian Network of Toxicology ed.), Ottawa,Ontario, Canada. Science and Technology. 6, 555-557.

Dalir, N., Karimian, N., Yasrebi, J., Ronaghi, A., 2013. Chemical forms of cadmium in a calcareous soil treated with different levels of phosphorus and cadmium and planted to spinach. Archives of Agronomy and Soil Science. 59, 559-571.

Das, D.K., 2000. Micronutrients: Their behaviour in soils and plants. pp 254255.

Elzein, A., Kroschel, J., Müller, D., 2004. Optimization of storage conditions for adequate shelf-life of "pesta" formulation of Fusarium oxysporum "Foxy 2", a potential mycoherbicide for Striga: effects of temperature, granule size and water activity. Biocontrol Science and Technology. 14, 545-559.

Gomez, K.A., Gomez, A.A. 1984. Statistical Procedure for Agricultural Research, $2^{\text {nd }}$ Edn. John Wiley and Sons, New York.

Hussain, M.J., Zhang, G., Zhu, Z., 2008. Influence of Cadmium toxicity on plant growth and nitrogen uptake in rice as affected by nitrogen form. Journal of Plant Nutrition. 31, 251-262.

John, M.K., Laerhoven, C.V., Chuah, H.H., 1972. Factors affecting plant uptake and phytotoxicity of cadmium added to soils. Environmental Science and Technology. 6, 1005-1009.

Kibria1, M.G., Osman, K.T., Ahmed, M.J., 2006. Cadmium and lead uptake by rice (Oryza sativa L.) grown in three different textured soils. Soil and Environment. 25, 70-77.

Liu, Y.T., Chen, Z.S., Hong, C.Y., 2011. Cadmium-induced physiological response and antioxidant enzyme changes in the novel cadmium accumulator, Tagetes patula. Journal of Hazardous Materials. 189, 724-731.

Martinez, F., Cuevas, G., Calvo, R., Walter, I., 2003. Biowaste effects on soil and nativeplants in a semiarid ecosystem. Journal of Environmental Quality. 32, 472-479.

Muramoto, S., Nishizaki, H., Aoyama, I., 
1990. The critical levels and the maximum metal uptake for wheat and rice plants when applying metal oxides to soil. Journal of Environmental Science and Health. 25, 273-280.

Padmaja, K., Prasad, D.D.K., Prasad, A.R.K., 1990. Inhibition of chlorophyll synthesis in Phaseolus vulgaris Seedlings by cadmium acetate. Photosynthetica. 24, 399-405.

Prasad, M.N.V., 1995. Cadmium toxicity and tolerance in vascular plants. Environmental and Experimental Botany. 35, 525-545.

Rai, V., Khatoon,.S, Bisht, S.S., Mehrotra, S., 2005. Effect of cadmium on growth, ultramorphology of leaf and secondary metabolites of Phyllanthus amarus Schum, and Thonn. Chemosphere. 61, 1644-1650.

Rathore, S.V.S., Dera, D.K., Chand, U., 1985. Studies of nitrogen nutrition through foliar spray of urea on the performance of African marigold. Udyarika. 5, 3740.

Root, R.A., Miller, R.J., Koeppe, D.E., 1975. Uptake of cadmium its toxicity and effect on the iron to zinc ratio in hydroponically grown corn. Journal of Environmental Quality. 4, 473-476.

Sadana, U.S., Singh, B., 1987. Yield and uptake of cadmium, lead and zinc by wheat grown in soil polluted with heavy metals. Journal of Plant Sciences Research. 3, 11-17.

Sharma, R.K., Agrawal, M., 2005. Biological effects of heavy metals: an overview.
Journal of Environmental Biology. 26, 301-313.

Stobart, A.K., Griffiths, W.T., AmeenBukhari, I., Sherwood, R.P., 1985. The effect of cadmium on the bio synthesis of chlorophyll in leaves of barley. Physiologia Plantarum. 63, 293-298.

Tran T.A., Popova L.P., 2012. Functions and toxicity of cadmium in plants: recent advances and future prospects. Turk Journal of Botany. 37, 1-13.

Van, A.F., Clijsters H., 1990. Effects of metals on enzyme activity in plants. Plant cell and environment. 13, 195206.

Wani, P.A., Khan, P.S., Zaidi, A., 2007. Impact of heavy metal toxicity on plant growth, symbiosis, seed yield and nitrogen and metal uptake in chickpea. Australian Journal of Experimental Agriculture. 47, 712-720.

WHO, (World Health Organization) Regional Office for Europe, 2012. Agency for Toxic Substances and Disease Registry Division of Toxicology and Human Health Sciences.

Wu, F., Dong, J., Cai, Y., Chen, F., Zhang, G., 2007. Differences in Mn uptake and subcellular distribution in different barley genotypes as a response to $\mathrm{Cd}$ toxicity. Science of the Total Environment. 385, 228-234.

Zhou, W.B., Qiu, B.S., 2005. Effects of cadmium hyperaccumulation on physiological characteristics of Sedum alfredii hance (Crassulaceae). Plant Science. 169, 737-745.

\section{How to cite this article:}

Archana Gupta, B.R. Maurya and Latare, A.M. 2017. Effect of Sewage Sludge and Cadmium on Growth and Quality Features of Marigold (Tagetes erecta L.) Grown in Three Soils. Int.J.Curr.Microbiol.App.Sci. 6(9): 2350-2359. doi: https://doi.org/10.20546/ijcmas.2017.609.288 